\title{
Hivatással és hálapénzzel kapcsolatos vélekedések a magyarországi családorvosok és családorvos rezidensek körében
}

\author{
Torzsa Péter dr. ${ }^{1}$ - Csatlós Dalma dr. ${ }^{1}$ - Eőry Ajándék dr. ${ }^{1}$ \\ Hargittay Csenge dr. ${ }^{1}$. Horváth Ferenc dr. ${ }^{2}$. László Andrea dr. ${ }^{1}$ \\ Márkus Bernadett dr. ${ }^{1}$ - Mohos András dr. ${ }^{4}$ - Kalabay László dr. ${ }^{1}$ \\ Győrffy Zsuzsa dr. ${ }^{3}$

\begin{abstract}
Semmelweis Egyetem, Általános Orvostudományi Kar, ${ }^{1}$ Családorvosi Tanszék, ${ }^{2}$ Népegészségtani Intézet, ${ }^{3}$ Magatartástudományi Intézet, Budapest

${ }^{4}$ Szegedi Tudományegyetem, Általános Orvostudományi Kar, Családorvosi Intézet és Rendelő, Szeged
\end{abstract}

\begin{abstract}
Bevezetés: A XXI. században a családorvosi hivatás változása figyelhető meg. Az elvándorlás, a gyógyítók elöregedése és a hálapénz kérdése meghatározóak az egészségügyi szektor humánerőforrás-krízise szempontjából. Célkitüzés: A szerző́k célul tűzték ki a hazai családorvosok és családorvos rezidensek hivatásról és a hálapénzrôl való vélekedéseinek feltárását. Módszer: Feltáró jellegü kvantitatív vizsgálat családorvosok $(\mathrm{n}=363$ ) és családorvos rezidensek ( $\mathrm{n}=180)$ körében. Jelen elemzés középpontjában a jövedelemre vonatkozó kérdések, a hálapénzzel és hivatással kapcsolatos vélemények álltak. Eredmények: A válaszadók hivatásválasztásában és hivatástudatában az altruizmus, a szolgálat és a felelősségvállalás a legmeghatározóbb tényezők. A paraszolvencia tekintetében a rezidensminta szignifikánsan elutasítóbb (19,7\% vs. 38,3\%; p<0,001). A rezidensek kisebb összeget tartanak elfogadhatónak (14,3\% vs. $8,9 \% ; \mathrm{p}<0,034)$, valamint nagyobb arányban mondják azt, hogy a befolyt jövedelmet praxisfejlesztésre fordítanák ( $1,4 \%$ vs. $9,4 \% ; \mathrm{p}<0,023)$. Következtetések: A családorvosok és a családorvos rezidensek hivatással kapcsolatos legfontosabb attitűdjei közel azonosak, de a hálapénz kérdéséról a két generáció másként vélekedik. Orv. Hetil., 2016, $157(36)$, 1438-1444.
\end{abstract}

Kulcsszavak: családorvos, családorvos rezidens, hivatás, hálapénz

\section{Opinions of Hungarian family physicians and residents on vocation and informal payment}

Introduction: The changing of the family medicine can be observed in the New Millennium. Migration, the aging of the healers and informal payment are crucial to the human resource crisis of the health sector. Aim: The aim of this study was to investigate the family physicians' and residents' opinions about the vocation and informal payment. Method: Exploratory, quantitative study was carried out among family physicians $(\mathrm{n}=363)$ and family physician residents $(\mathrm{n}=180)$. The central questions of the study were the vocation, the income and the informal payment. Results: The most decisive factors of the carrier choice were altruism, service and responsibility. Residents were significantly rejective $(19.7 \%$ vs. $38.3 \%, \mathrm{p}<0.001)$ about informal payment. They would accept smaller amounts of informal payment $(14.3 \%$ vs. $8.9 \%, \mathrm{p}<0.034)$, and would spend it on praxis development $(1.4 \%$ vs.9.4\% $\mathrm{p}<0.023)$. Conclusions: The attitudes of family physicians and residents are the same in case of the vocation, but on the issue of informal payment, the two generations have different opinions.

Keywords: family physician, family physician resident, vocation, informal payment

Torzsa, P., Csatlós, D., Eöry, A., Hargittay, Cs., Horváth, F., László, A., Márkus, B., Mohos, A., Kalabay, L., Györffy, Zs. [Opinions of Hungarian family physicians and residents on vocation and informal payment]. Orv. Hetil., 2016, 157(36), 1438-1444.

(Beérkezett: 2016. június 5.; elfogadva: 2016. június 30.) 
A XXI. században az orvoslás - ezen belül a családorvosi hivatás is - dinamikus átalakuláson megy keresztül. E változás része a deprofesszionalizáció folyamatának, amelyben egyre hangsúlyosabbá válik a hivatás szolgáltatás jellege, a technicizálódás, az orvosi autonómia csökkenése [1-4]. Ebben a folyamatban a klasszikus hivatásfogalom alapösszetevőinek egy része változatlanul igen fontos marad: az altruizmus és a speciális tudás továbbra is a hivatás meghatározó elemei. Ugyanakkor a profeszszió további elemeiben - az autonómia, a monopólium, a presztízs, az erkölcsi és anyagi elismerés volumenében már változások figyelhetők meg. Úgy tűnik, hogy a karizmatikus, „szolgáló” gyógyítói szerep mellett egyre inkább megjelenik a XXI. századi szolgáltató szakember profilja [5].

Ezzel az átalakulással párhuzamosan változások figyelhetők meg a fiatal generációk pálya- és szakválasztási motivációiban: az altruisztikus értékek mellett a hivatásválasztásban egyre meghatározóbb szerepet kap a természettudományos érdeklődés, illetve a financiális és karrierlehetőségek. A szakválasztás esetében is egyre inkább megfigyelhető a „controllable lifestyle” jelensége, vagyis a szakmai érdeklődés mellett egyre fontosabbá válik a szakmához kapcsolódó időbeosztás, jövedelem és presztízs. A nemzetközi vizsgálatok azt mutatják, hogy megnőtt azon szakmák iránt az érdeklődés, amelyekben nincs éjszakai munkavégzés, kiszámítható a munkaidő, minimálisak a váratlan, kiszámíthatatlan helyzetek [6]. A „kontrollálható életstílus” jellemző a családorvosi hivatásra is, hiszen a „munkaido”” és a „családi idő” összeegyeztethetősége talán könnyebben megvalósítható, mint más orvosi szakágak esetében.

Magyarországon az orvosi hivatás átalakulása sajátos társadalmi, gazdasági, egészségpolitikai közegben megy végbe. Az orvosok elvándorlása, a gyógyítók elöregedése és nyugdíjba vonulása, valamint a hálapénz kérdése meghatározók az „egészségügyi szektor” humánerőforráskrízise szempontjából. Ahogyan egy 2011-es hazai vizsgálat is jelzi, a külföldi munkavállalási szándék legfőbb motivációs tényezői a fizetés, az „életminőség”, a magyar egészségügy kilátásai, a munkakörülmények, a társadalmi megbecsültség és a szakmai lehetőségek [7]. Jelentős probléma továbbá a magyarországi orvostársadalom elöregedése: jelenleg a legnagyobb számban az 55-60 év közötti orvosok praktizálnak Magyarországon, komoly hiány mutatkozik egy-egy népesebb kohorsz nyugdíjba vonulásakor [8]. A háziorvosi praxisok elöregedése és kiüresedése hosszú évek óta a magyar egészségügy egyik legnagyobb gondja. Míg 2006-2007-ben közel 200 tartósan betöltetlen háziorvosi praxist tartottak nyilván, addig ez a szám 2016-ra 314-re emelkedett [9]. A betöltetlen praxisok mellett a családorvosok „elöregedése" is jelentôs probléma: míg az ezredfordulót megelőzôen inkább a harmincas éveik elején léptek be a praxisba a háziorvosok, addig a 2010-es évekre egyre jellemzőbbé vált, hogy a belépő háziorvosok átlagéletkora 40-45 év közé esik. Az átlagéletkorra vonatkozó adatok azt mutatják, hogy a hazai háziorvosok átlagéletkora 56,1 év [9]. 2016 áprilisában a praktizáló orvosok 10\%-a 70 év feletti, ami azt jelenti, hogy az elkövetkező években a betöltetlen praxisok száma tovább növekszik.

A magyar egészségügy további problémája a hálapénzkérdés. A KSH folyamatosan emelkedő lakossági kifizetésekról ad számot (míg 8,3 milliárd forintra becsülte a 2014-ben hálapénzre kifizetett összeget, ez 1998-ban még csak 3 milliárd forint körül mozgott [10]). A hálapénz fontos vizsgálati terület hazánkban, azonban a kutatások legnagyobb része a lakossági motivációkra, kifizetésekre és azok megoszlására irányul, csekély azon vizsgálatok száma, amely az orvostársadalom szempontjából vizsgálná a kérdést. E témában igen fontos az a 2009-2010-ben készült felmérés, amely a hazai IV. éves orvostanhallgatók körében készült: e felmérés eredményei szerint a medikusok és medikák mintegy 61\%-os arányban fogadnának el hálapénzt. Az összeg nagyságát, úgy gondolták, leginkább a beteg anyagi helyzete határozza meg [11]. E felmérést megelőzően a Szinapszis Kft. 2009-ben készített online felmérése arról adott számot, hogy az orvosok 10\%-a soha nem fogad el hálapénzt, azonban jelentős részük (81\%) elfogadja, de nem minden esetben. A tanúsított hozzáállást alapvetően a beteg szociális helyzete (70\%) és a betegség jellege (30\%) határozza meg [12]. A felmérés szerint az orvosok 57\%-a az alacsony bérek miatt nélkülözhetetlennek tartja a hálapénzt, további 6\%-uk véli úgy, hogy az állam a betegekkel pótoltatja az orvosok fizetését. A Magyar Rezidens Szövetség megbízásából 2013-ban a Szinapszis Kft. ismét felmérte a hálapénzzel kapcsolatos vélekedéseket. Az eredmények tanúsága szerint a megkérdezettek 78\%-a fogad el rendszeresen hálapénzt, de az orvosok döntő többsége (70\%-nyi) mérlegeli, hogy mikor, kitől, milyen körülmények között fogadja el. A vizsgálat fontos eredménye, hogy a megkérdezett orvosok 70\%-a elviekben elutasítja a hálapénzt, ugyanakkor a jelenlegi viszonyok között szükségesnek tartja az elfogadását [13].

A fenti nagyon fontos egészségpolitikai és kutatási kérdések inspirálták vizsgálatunkat és elemzésüket. A következőkben a magyarországi családorvosok és családorvos rezidensek hivatással, valamint jövedelemmel és hálapénzzel kapcsolatos vélekedéseit tekintettük át az alábbi hipotézisek mentén:

1. A fiatalabb orvosi generáció tagjai elutasítóbbak a hálapénzzel kapcsolatban.

2. A hivatástudat „szolgálat” jellege negatív kapcsolatot mutat a hálapénz elfogadásával.

\section{Módszer}

Kvantitatív vizsgálatunkat 2014-ben és 2015 öszén folytattuk le, önkitöltős, papíralapú kérdőív segítségével. A Semmelweis Egyetemen, két kötelező szinten tartó tanfolyam keretében 650 családorvost kerestünk meg kérdőívünkkel, amelyet 363 családorvos töltött ki (válaszadási arány: 56\%). A rezidensi referálókon 180 csa- 
ládorvos rezidens töltötte ki a kérdőíveket (válaszadási arány: 96\%).

Kutatásunk fő témakörei a következők voltak:

1. Demográfiai adatok (életkor, lakóhely, családi állapot, gyermekek száma).

2. Munkahelyre vonatkozó adatok (munkahely típusa, jelenlegi szakterület, szakvizsgák száma, ügyeletek száma, mellékállások, magánpraxisok, előző munkahelyek, munkaidő mennyisége).

3. Pszichológiai tényezők (depresszió, kiégés).

4. Jövedelemre és a hálapénzre vonatkozó kérdések.

5. Hivatásválasztásra és a hivatás attribútumaira vonatkozó kérdések.

Jelen elemzésünk középpontjában a jövedelemre vonatkozó kérdések, a hálapénzzel és hivatással kapcsolatos vélekedések elemzése áll. Írásunkban minden vizsgálati terület elemzésekor bemutatjuk az adott kérdést és a rá adható válaszlehetőségeket, illetve jelen közleményünk mellékletében megtekinthetők a kérdőív eredeti kérdései.

\section{Statisztikai módszerek}

Deskriptív elemzésünk során a családorvosi minta és a családorvos rezidensi minta összehasonlítását végeztük el, ahol a folytonos változók esetében átlagokat, míg a diszkrét változók között gyakoriságokat vizsgáltunk. A vizsgált változók közötti százalékos eltéréseket is jeleztük. A változók típusa szerint független mintás t-próbát, illetve $\chi^{2}$-próbát alkalmaztunk. Elemzésünkben minden esetben az érvényes válaszok arányait vizsgáljuk. Az adatok statisztikai elemzése az SPSS 22.0 programmal történt.

\section{Eredmények}

A háziorvosi minta leíró jellemzői a következőképpen alakultak: 363 háziorvos adott értékelhető választ kérdéseinkre. A válaszadók 57,6\%-a (209) volt nő. Az átlagéletkor 58,4 év (SD 10,8) volt, a legnagyobb arányban (34\%) az 51-60 és a 61-70 éves korosztály (34\%) tagjai képviseltetik magukat. A megkérdezett háziorvosok átlagosan 20,4 éve (SD: 10,8) dolgoznak praxisukban. Legnagyobb arányban $(89,9 \%)$ vállalkozó orvosként dolgoznak, kisebb arányban közalkalmazottként (3,9\%) és alkalmazottként $(1,7 \%)$, és 3,1\%-nyian nyugdíjasok. A praxis típusát tekintve $81,7 \%$ a felnőttpraxisban dolgozók aránya, $5,1 \%$ a gyermekpraxisban dolgozók aránya, míg 12,3\% dolgozik vegyes praxisban.

A válaszadók 49,6\%-a budapesti, 6,5\%-a megyeszékhelyi, 25,8\%-a városi, míg 16,7\%-a falusi praxisban dolgozik. A megkérdezettek átlagos kártyaszáma 1768 fó (SD: 562), míg az átlagos szakvizsgaszám medián értéke kettő. A megkérdezettek 73,7\%-a nem ügyel, míg 26,3\%-a rendszeresen ellát ügyeleti munkát.

A családi állapot mutatóit tekintve elmondható, hogy 77,6\% házastárssal vagy élettárssal él, és közel ugyanany- nyian vannak az egyedülállók, illetve az elváltak. Az átlagos gyermekszám 2, legnagyobb arányban $(44,8 \%)$ vannak a kétgyermekesek, 28,8\% a három- és többgyermekesek aránya, 19,4\% az egygyermekeseké, míg a minta $7,75 \%$-ának nincs gyermeke.

\section{A háziorvos rezidensi minta leíró jellemzői}

Kérdőívünkre 180 rezidens válaszolt, akik közül 22,3\% (40) a férfi és 77,2\% (139) a nő. A válaszadók átlagéletkora 32,5 év, legnagyobb arányban a 26-31 évesek $(62,5 \%)$, majd a 3l-38 évesek (21\%) és 39-48 évesek (16,5\%) kerültek a mintába. A válaszadók 79\%-a nem ügyel, míg 21\%-uk lát el ügyeleti munkát. A válaszadók 97\%-a nem rendelkezik szakvizsgával.

Családi állapot tekintetében a legnagyobb arányban a partnerkapcsolatban élők $(65,4 \%)$ vannak, 31,3\% az egyedülállók aránya. A gyermekszám tekintetében elmondható, hogy a válaszadó rezidensek közel felének $(46,9 \%)$ egy gyermeke van, $31,2 \%$ a többgyermekesek aránya és $22,3 \%$-nak nincs gyermeke.

\section{A pályaválasztás motivációi a háziorvosi és a rezidensi mintában}

Elmondható, hogy mindkét csoport esetében a hivatásválasztás legfőbb motivációja a „betegek gyógyításának” igénye $(72 \%$-uk jelölte a háziorvosi, míg $77 \%$ a rezidensi mintában). Ugyanakkor a hivatásválasztás további motivációit tekintve különbséget találunk a két csoport között: a háziorvosi csoport esetében a hivatásválasztás második legfontosabb indoka a szakma magas presztízse, majd ezt követi a szülői példa követése. Ezzel ellentétben rezidensek esetében a kutatás lehetősége a pályaválasztás második legfontosabb indoka, ezt követi a szülői hatás jelentősége, majd utolsó előtti helyen jelölték az orvosi hivatás magas presztízsét a pályaválasztás indokául (1. táblázat). Ugyanakkor a rezidensi mintában szignifikánsan nagyobb arányban $(20,2 \%$ vs. $30,6 \%$, p<0,001) találunk orvos vagy egészségügyi dolgozó szülőket, így a „szülői hatás” implicit jelentősége mégis meghatározó.

\begin{tabular}{l|l} 
1. táblázat & $\begin{array}{l}\text { A hivatásválasztás motivációi a családorvosok és a családorvos } \\
\text { rezidensek körében (E kérdés esetében a válaszadók több lehe- } \\
\text { tőséget is megjelölhettek) }\end{array}$
\end{tabular}

\begin{tabular}{llll}
\hline $\begin{array}{l}\text { Hivatásválasztás } \\
\text { motivációi }\end{array}$ & $\begin{array}{l}\text { Családorvosok } \\
(\%), \\
\mathrm{n}=363\end{array}$ & $\begin{array}{l}\text { Családorvos } \\
\text { rezidensek } \\
(\%), \mathrm{n}=178\end{array}$ & $\begin{array}{l}\text { p-érték } \\
\text { a } \chi^{2} \text {-próba } \\
\text { alapján }\end{array}$ \\
\hline $\begin{array}{l}\text { Betegek gyógyítása } \\
\text { Társadalmi } \\
\text { megbecsültség }\end{array}$ & 72 & 77 & $\mathrm{NS}$ \\
$\begin{array}{l}\text { Szülói hatás } \\
\text { Kutatóorvoslás }\end{array}$ & 9,1 & 3,9 & 0,028 \\
$\begin{array}{l}\text { „Nem lesznek anyagi } \\
\text { gondjaim” }\end{array}$ & 4,2 & 4,5 & 0,032 \\
\hline
\end{tabular}




\section{Vélemények az orvosi és a családorvosi hivatásról}

A kérdéskör esetében a válaszadók elsóként az orvosi, majd a családorvosi hivatás presztízsét ítélték meg. A háziorvosi válaszadók közel fele $(44,5 \%)$ kifejezetten rossznak, míg 43,9\%-uk közepesnek ítélte az orvosi hivatás jelenlegi presztízsét Magyarországon. A rezidensek szignifikánsan gyakrabban jelölték a „közepes” kategóriát $(64,2 \%, p<0,001)$, mintegy $24,2 \%$-nyian tartják az orvosok társadalmi presztízsét kifejezetten rossznak, és 11,2\%-nyian jónak.

Az orvosi hivatás általános megítéléséhez képest a családorvosok presztízsét a háziorvosok legnagyobb arányban közepesre (43,9\%) osztályozzák, és mintegy egyötödük $(20,8 \%)$ tartja jónak a választott szakmája presztízsét. A rezidensek szignifikánsan nagyobb mértékben tartják a szakma presztízsét közepesnek $(58,8 \%, \mathrm{p}<0,023)$, és valamivel kisebb mértékben ítélik jónak (16,9\%). Közel hasonló $(26,8 \%$ vs. $23,7 \%)$ azok aránya, akik mindkét csoportban kifejezetten rossznak tartják a családorvosi szakma társadalmi megítélését.

A következő kérdésben arról kérdeztük a válaszadókat, hogy mit tartanak a családorvosi hivatás legfontosabb ismérvének. E kérdés esetében elsöprő többséggel jelent meg a „szolgálat” jellemző, mindkét csoport esetében $(65,9 \%$ vs. $60,9 \%)$. Ezt követte a „szolgáltatás” jellemző (28,9\% vs. 29,6\%). Különbségként rajzolódik ki a két csoport között, hogy a rezidensek szignifikánsan nagyobb arányban tartják választott hivatásukat múvészetnek ( $11,9 \%$ vs. $19 \% ; \mathrm{p}<0,023)$ (2. táblázat).

Ugyancsak hasonló azon válaszok megoszlása, amelyben az orvosi hivatás legfontosabb „kritériumaira”, attribútumaira kérdeztünk rá. A válaszadók közel háromnegyede $(77,4 \%$ vs. $70,8 \%)$ a legfontosabbnak a felelösséget vélte, de míg a rezidensek esetében a második helyre a "mások tisztelete" (65\%) került, addig a háziorvosi csoportban a második leggyakoribb válasz a „becsületesség” $(62,9 \%)$ volt. Ezt követte mindkét csoport esetében a „szolgálat” (51,7\% vs. 53\%). A „kiválóság” attribútum esetében nagy a különbség a két csoport között: a rezidensek szignifikánsan gyakrabban jelölték ezt a lehetőséget (3. táblázat).

\section{Jövedelmi helyzet és a hálapénzzel kapcsolatos vélekedések}

Kérdőívünkben elsóként arra kérdeztünk, hogy „Ön szerint ma Magyarországon mennyi pénzt kellene kapnia egy orvosnak (nettó értékben)?”

A háziorvosi mintában a válaszadók legnagyobb arányban $(68,2 \%)$ a 400000 forint feletti kategóriát jelölték, míg a második leggyakoribb válasz a 300 000-400 000 forintos lehetőség volt (26,4\%). Legkevesebben a 200 000-300 000 forintos összeghatárt jelölték (4,3\%). A háziorvosok válaszaihoz képest jelentős különbséget mutattak a rezidensek válaszai: 39\%-uk véli úgy, hogy 400000 forint feletti lenne az „álomfizetés”, 37\%-nyian
2. táblázat $\mid$ A családorvosi hivatás legfontosabb jellemzői (E kérdés esetében a válaszadók több választ is megjelölhettek)

\begin{tabular}{llll}
\hline $\begin{array}{l}\text { Családorvosi hivatás } \\
\text { legfontosabb } \\
\text { jellemző́i }\end{array}$ & $\begin{array}{l}\text { Családorvosok } \\
(\%), \\
\mathrm{n}=363\end{array}$ & $\begin{array}{l}\text { Családorvos } \\
\text { rezidensek }(\%), \\
\mathrm{n}=179\end{array}$ & $\begin{array}{l}\text { p-érték } \\
\mathrm{a} \chi^{2} \text {-próba } \\
\text { alapján }\end{array}$ \\
\hline Szolgálat & 65,9 & 60,9 & $\mathrm{NS}$ \\
\hline Szolgáltatás & 28,9 & 29,6 & $\mathrm{NS}$ \\
\hline Müvészet & 11,9 & 19 & 0,023 \\
\hline Bérmunka & 5,4 & 6,7 & $\mathrm{NS}$ \\
\hline
\end{tabular}

3. táblázat A családorvosi hivatás legfontosabb attribútumai (E kérdés ese tében a válaszadók több válaszlehetőséget is megjelölhettek)

\begin{tabular}{llll}
\hline $\begin{array}{l}\text { Családorvosi hivatás } \\
\text { legfontosabb } \\
\text { attribútumai }\end{array}$ & $\begin{array}{l}\text { Családorvosok } \\
(\%), \\
\mathrm{n}=363\end{array}$ & $\begin{array}{l}\text { Családorvos } \\
\text { rezidensek }(\%), \\
\mathrm{n}=175\end{array}$ & $\begin{array}{l}\text { p-érték } \\
\text { a } \chi^{2} \text { próba } \\
\text { alapján }\end{array}$ \\
\hline Felelősség & 77,4 & 70,8 & 0,052 \\
\hline Becsületesség & 62,9 & 63,1 & $\mathrm{NS}$ \\
\hline Mások tisztelete & 61,4 & 65 & $\mathrm{NS}$ \\
\hline Szolgálat & 51,7 & 53 & $\mathrm{NS}$ \\
\hline Önzetlenség & 42,4 & 40,7 & $\mathrm{NS}$ \\
\hline Kiválóság & 32,4 & 52 & 0,001 \\
\hline
\end{tabular}

lennének elégedettek 300 000-400 000 forinttal, míg 27\%-nyian elfogadhatónak tartják a 200 000-300 000 forint közötti nettó jövedelmet.

Következő kérdésünk a hazai orvosi fizetések megoszlására irányult. E kérdés esetében a háziorvosok 76,1\%-a úgy vélte, hogy az átlagos nettó jövedelem 200000 300000 forint között mozog, 23,9\%-nyian gondolják azt, hogy ennél magasabb jelenleg az orvosi átlagfizetés Magyarországon. A rezidensek ezzel szemben úgy vélik, hogy ma Magyarországon 100 000-200 000 forint között keres egy orvos $(82,8 \%)$, mindössze $17,2 \%$ azok aránya, akik ennél többre becsülték a gyógyítói átlagkereseteket.

Ezután kérdeztünk rá a hálapénzzel kapcsolatos attitüdökre, „szokásokra”, viselkedésre. A háziorvosi mintában 19,7\%-nyian voltak azok, akik azt válaszolták, hogy a hálapénz „nem fogadható el”, míg a rezidensek 38,3\%-a utasítja el a hálapénz minden formáját $(\mathrm{p}<0,001)$. A hálapénzzel kapcsolatban „megengedőbbek" legnagyobb arányban azt válaszolták, hogy alkalmanként és a végzett munkától függően maximum ötezer forint értékben fogadható el (40,6\% [háziorvosok] vs. $37,2 \%$ [rezidensek], p<0,123). Ezt követi az a leggyakoribb válasz, hogy „elfogadható alkalmanként és a végzett munkától függően, felső értékhatár nélkül” (22,5\% vs. $15,6 \%, \mathrm{p}<0,034)$. A megkérdezett háziorvosok 14,3\%-a jelezte, hogy ennél nagyobb összeget is elfogadhatónak tart, míg a rezidensek $8,9 \%$-a jelölt ötezer forintnál magasabb összeget $(\mathrm{p}<0,041)$. 
A következő kérdésben a hálapénz elfogadásának körülményeire kérdeztünk rá. Azon háziorvosok és rezidensek közül, akik a hálapénz elfogadása mellett tették le a voksukat, legtöbben úgy vélik, hogy „elfogadható, ha a beteg anyagi helyzete a hálapénz adását megengedi” (47,\% vs. 37,8\%, p<0,012). Ezt követte, második leggyakoribb válaszként „Elfogadható, hiszen jó munkát végzek, ezért kapom” válaszlehetőség jelölése, majd pedig az „Elfogadható, praxisfejlesztésre vagy jótékonysági célra" állítás választása.

A fenti kérdésekkel összefüggésben megkérdeztük azt is, hogy mit gondolt pályakezdőként a hálapénz elfogadásáról. E kérdés esetében a rezidensek szignifikánsabban nagyobb arányban válaszolták azt, hogy mindenképpen elutasítanák (10,9\% vs. $27,2 \%, \mathrm{p}<0,001)$, ezt követte a „ha a beteg anyagi helyzete megengedi” lehetóség jelölése $(40,5 \%$ vs. $46,7 \%, p<0,053)$. Fontos különbségként rajzolódott ki, hogy a rezidensek pályakezdőként nagyobb arányban gondolták (gondolják) úgy, hogy a hálapénzt praxisfejlesztésre fordítanák (1,4\% vs. 9,4\%, $\mathrm{p}<0,001)$.

Eredeti hipotézisünkkel szemben nem találtunk összefüggést a hivatástudat „szolgálat” jellege és a hálapénz elfogadása, illetve elutasítása között.

A hálapénzzel kapcsolatosan legutolsóként arra kérdeztünk rá, hogy a hálapénz elfogadása esetén mi határozza meg a hálapénz mértékét, volumenét. E kérdés esetében mindkét csoportnál egyértelműen kirajzolódott $(58,9 \%$ vs. $59,3 \%)$, hogy a beteg anyagi helyzete a döntő a hálapénz elfogadásakor. Az orvos teljesítménye kisebb jelentőségű a hálapénz nagyságában.

A következő lépésben a hálapénz elfogadásának és elutasításának különböző háttértényezőit igyekeztünk felderíteni, azonban sem „személyes tényezők” (családi állapot, gyerekszám, valláshoz való viszony), sem a munkavégzés különböző aspektusait tekintve nem találtunk kimutatható, szignifikáns különbséget a két csoport között. Eredeti hipotéziseinkkel szemben nincs különbség a hivatásválasztás különböző motivációival és az orvosi hivatás különböző attribútumaival sem. A fő különbség az életkori dimenziók mentén rajzolódott ki: a fiatalabb orvosgeneráció szignifikáns mértékben elutasítóbb a hálapénz minden formájával szemben.

\section{Következtetések}

Vizsgálatunk középpontjában a magyarországi családorvosok és rezidensek hivatással és paraszolvenciával kapcsolatos attitû́djei álltak. Kutatásunk megerősítette, hogy a magyarországi „családorvos-társadalom” dinamikus változásban van: a magas átlagéletkor és az „elnőiesedo”” hivatás egyaránt jellemzői e változásoknak.

A Magyar Orvosi Kamara által nyilvántartott hazai orvosok közül ( $n=46044$ fó) 2015-ben mintegy 10724 fö a nyugdíjas orvosok körébe tartozott. Ez azt jelenti, hogy a magyarországi orvostársadalom közel egynegyede nyugdíjas, a magyarországi orvosok átlagéletkora igen magas, elmondható, hogy a hazai gyógyítók több mint fele 50 évesnél idősebb. Az érvényes múködési nyilvántartással rendelkező orvosok esetében az életkori csoportok emelkedő arányt mutatnak: a legnépesebb mind közül az 55-59 éves korosztály, amely elörevetíti azt, hogy egy évtizeden belül a legnépesebb orvosi csoport nyugdíjas korúvá vagy inaktívvá válik [8].

Az „elöregedő orvoslás és háziorvoslás” jelenségével párhuzamosan megfigyelhető az is, hogy a nők száma dinamikusan emelkedő tendenciát mutat. E jelenség azonban nem új keletü folyamat: az elmúlt évtizedekben az orvosnők száma dinamikusan emelkedik világszerte, látványos a növekedés például az Egyesült Államokban, ahol 50 évvel ezelőtt a nők aránya az egyetemeken $10 \%$ körül mozgott, míg ma a hallgatók több mint fele nő [14]. Míg a kilencvenes évek jóslatai azt prognosztizálták 2010-re, hogy csak minden harmadik gyógyító lesz nő, mára kiderült, hogy az orvosi pályát választók és gyakorlók együttesen közel 50\%-os arányban nők [15-17]. Jellemzôvé vált az is, hogy a világ orvosegyetemein már több mint $60 \%$-os a női hallgatók aránya $[18,19]$. A magyarországi helyzet némileg különbözik az egyesült államokbeli, illetve az európai tendenciáktól. Hazánkban ugyanis - Lengyelországhoz hasonlóan - már az 1950-es évektől kezdve sok nő vesz részt az orvosképzésben és gyakorolja az orvosi hivatást [20]. Ugyanakkor az elnőiesedés trendje hazánkban is megfigyelhető: a KSH adatai alapján elmondható, hogy a fiatal (26-29 éves) korosztályban az orvosnók aránya kétszerese (1630 vs. 834 fó) a férfi orvosokénak [21]. Az elvándorlás és a pályaelhagyás [22] minden bizonnyal komoly tényező a szakma elnőiesedésében, mert a magyarországi adatok azt mutatják, hogy 2009-2014 között mind a négy magyarországi orvosegyetemre a nők csak 10\%-kal jelentkeztek nagyobb arányban: a női és férfi hallgatók megoszlása 55 vs. $45 \%$ volt. Az ugyanebben az időszakban az egyetemet sikeresen elvégzettek aránya ezzel megegyezik: szintén $55 \%$ a nők és $45 \%$ a férfiak aránya [17]. Tehát míg a végzett hallgatók arányában nincs jelentős nemek szerinti különbség, addig a rezidensképzésbe belépók esetében már közel 50\%-os női többlet mutatható ki.

Elmondható továbbá az is, hogy a válaszadóink hivatásválasztásában egyértelmúen az altruisztikus tényezők játszották a legnagyobb szerepet, ugyanakkor a rezidensgeneráció pályamotivációi között a tudományos érdeklődés igénye egyre markánsabb szerepü. Ezen eredményünk egybevág más magyarországi vizsgálatok adataival, amelyek jelezik, hogy napjaink medikusai és medikái pályaválasztási motivációi között egyre jelentősebb szerepet kap a természettudományos érdeklődés [17, 23]. Ugyanakkor fontos azt is hangsúlyoznunk, hogy mindkét minta esetében a hivatás legfontosabb attribútumának a „szolgálat” bizonyult, a szakma „szolgáltatás” jellegét jóval kevesebb válaszadó jelölte, így a deprofeszszionalizáció trendje jelen mintákban egyértelmüen nem rajzolódik ki. Mindezzel párhuzamosan mindkét „gene- 
ráció” egybehangzóan a felelősségvállalást jelölte a hivatás legfontosabb alapkövetelményének.

A jövedelem és a paraszolvencia kérdését tekintve elmondható, hogy mindkét csoport a 400000 forint feletti fizetést tartaná elfogadhatónak, továbbá mindkét orvosi csoport jóval alacsonyabbra pozicionálta a jelenlegi átlagfizetéseket. A hálapénz tekintetében a fiatalabb orvosi generáció (rezidensminta) egyértelműen elutasítóbb, és nagyobb arányban jelezték, ha elfogadják a hálapénzt, akkor azt praxisfejlesztésre fogják fordítani. A Markusovszky-ösztöndíj is sokat segített abban, hogy a rezidensek nagyobb arányban utasítják el a hálapénzt. Az azonban egyértelmű mindkét csoportban, hogy a hálapénz elfogadásának legfontosabb tényezője a beteg (anyagi) helyzete. Vizsgálatunkban tehát kirajzolódik - a napjaink közéletét is meghatározó - trend, amely azt mutatja, hogy a fiatalabb családorvos-generáció tagjai egyértelmúen elutasítóbbak a hálapénzzel szemben. A hivatástudattal kapcsolatos kérdéseink és a hálapénz elfogadása közti kapcsolat sem mutatott szignifikáns öszszefüggést, így feltehetően e kérdések hátterében is jóval összetettebb folyamatok húzódnak meg.

Vizsgálatunk „pilot study”-ként szolgál egy családorvos rezidensek helyzetét feltáró nagyobb léptékü kuta- táshoz. Célunk a hivatástudat, a paraszolvenciával kapcsolatos vélekedések és a migrációs szándék egyidejü feltérképezése volt, kutatásunk erőssége és egyben hátránya a sok szempontú megközelítés, amely csak deskriptív elemzést tett lehetővé. Vizsgálatunk erőssége ugyanakkor, hogy lehetővé vált a két, gyakorló orvosgeneráció fenti dimenziók mentén való összehasonlítása. További célunk, hogy a fiatal családorvos-generáció körében a hálapénz problémáját és a külföldi munkavállalás, illetve pályaelhagyás kérdését széles körü vizsgálat alá vonjuk.

Anyagi támogatás: A közlemény megírása, illetve a kapcsolódó kutatómunka anyagi támogatásban nem részesült.

Szerzői munkamegosztás: T. P., K. L.: A kézirat megírása, a táblázatok összeállítása. Cs. D., M. B., E. A., L. A., M. A., H. Cs., H. F.: Szakirodalmi feldolgozás és a kézirat megírása. K. L.: A kézirat megírása. Gy. Zs.: A kézirat megírása és javítása. A cikk végleges változatát mindegyik szerző elolvasta és jóváhagyta.

Érdekeltségek: A szerzőknek nincsenek érdekeltségeik.

\section{Melléklet}

A családorvosi és a rezidensi felmérés jövedelemre, hálapénzre és hivatásra vonatkozó kérdései

Jövedelemmel és a hálapénzzel kapcsolatosan az alábbi kérdéseket tettük fel:

"Mennyi pénzt kellene kapnia egy orvosnak (nettóban)"?

A válaszlehetőségek: 100 000; 100 000-200 000; 200 000-300 000; 300 000-400 000; 400000 Ft felett

„Ön szerint mennyi az orvosi átlagfizetés nettóban?”

A válaszlehetőségek: 100 000; 100 000-200 000; 200 000-300 000; 300 000-400 000; 400000 Ft felett

„Ön szerint elfogadható-e a hálapénz és ha igen, akkor mennyi?”

A válaszlehetőségek: 1. Nem fogadható el. 2. Igen, elfogadható alkalmanként és a végzett munkától függően - maximum 5000 Ft. 3. Igen, elfogadható alkalmanként és a végzett munkától függően - maximum $50000 \mathrm{Ft}$. 4. Igen, elfogadható alkalmanként és a végzett munkától függóen - maximum $100000 \mathrm{Ft}$. 5. Igen, elfogadható alkalmanként és a végzett munkától függően - nincs felső határa.

„Mit tartott a hálapénzről pályakezdőként?”

A válaszlehetőségek: 1. Sosem fogadható el. 2. Elfogadható, de csak praxisfejlesztésre vagy jótékonysági célra. 3. Elfogadható, ha a beteg anyagi helyzete a hálapénz adását megengedi. 4. Elfogadható, hiszen jó munkát végzek, és ezért kapom.

„Mit tart jelenleg a hálapénzról?”

A válaszlehetőségek: 1. Sosem fogadható el. 2. Elfogadható, de csak praxisfejlesztésre vagy jótékonysági célra. 3. Elfogadható, ha a beteg anyagi helyzete a hálapénz adását megengedi. 4. Elfogadható, hiszen jó munkát végzek, és ezért kapom.

"Ön szerint a hálapénz mértékét mi határozza meg?”

A válaszlehetőségek: 1 . A beteg anyagi helyzete. 2 . Az orvos teljesítménye.

Az orvosi hivatásválasztásra vonatkozóan az alábbi válaszlehetôség közül választhattak a megkérdezettek:

A szüleim is orvosok, az ő példájukat követtem. Betegeket szerettem volna gyógyítani. Az orvosnak nagy a társadalmi megbecsülése, ez vezérelt. Azt gondoltam, orvosként nem lesznek anyagi gondjaim. Kutató orvos szerettem volna lenni.

A családorvosi hivatás legfőbb jellemzőit az alábbi válaszlehetőségek alapján jelölhették a megkérdezettek: Bérmunka. Múvészet. Szolgálat. Szolgáltatás.

Végül megkérdeztük, hogy mely attribútumok a legfontosabbak a családorvosi hivatásban (önzetlenség, felelősség, szolgálat, kiválóság, becsület és feddhetetlenség, mások tisztelete), amelyet egy négyfokú Likert-skálán (nagyon fontos, fontos, szükséges, nem fontos) értékelhettek a megkérdezettek. 


\section{Irodalom}

[1] Kanter, M. H., Nguyen, M., Klau, M. H., et al.: What does professionalism mean to the physician? Perm. J., 2013, 17(3), 8790 .

[2] Lucey, C., Souba, W.: Perspective: the problem with the problem of professionalism. Acad. Med., 2010, 85(6), 1018-1024.

[3] Tsou, A. Y., Creutzfeldt, C. J., Gordon, J. M.: The good doctor: professionalism in the 21 st century. Handb. Clin. Neurol., 2013, 118, 119-132.

[4] Kapocsi, E.: Crisis or renewal. Medical profession on the crossroad. [Válság vagy megújulás. Válaszúton az orvosi hivatás.] Lege Artis Med., 2004, 14(1), 72-75. [Hungarian]

[5] Kapocsi, E.: Unhappy doctors - phenomena what's behind it? [ „Boldogtalan orvosok” - a jelenség és ami mögötte van.] Lege Artis Med., 2011, 21(8-9), 584-588. [Hungarian]

[6] Heiligers, P. J.: Gender differences in medical students' motives and career choice. BMC Med. Educ., 2012, 12, 82.

[7] Girasek, E., Csernus, R., Ragány, K., et al.: Migration in the health sector. [Migráció az egészségügyben.] Magyar Tudomány, 2013, 174(3), 292-298. [Hungarian]

[8] Health Registration and Training Center: Human resource report of the Health Sector in Hungary - 2014. [Egészségügyi Nyilvántartási és Képzési Központ: Beszámoló az egészségügyi ágazati humánerőforrás 2014. évi helyzetéről az egészségügyi ágazati humánerőforrás-monitoringrendszer alapján.] http:// www.enkk.hu/hmr/documents/beszamolok/HR_beszamolo_2014.pdf [Hungarian]

[9] Lóránth, I.: Few patient, unviable praxis. [Kevés páciens, életképtelen praxis.] Orvosok Lapja, 2016, 4, 14-16. [Hungarian]

[10] Hungarian Central Statistical Office: Copayment and informal payment. [Központi Statisztikai Hivatal: Borravaló és hálapénz.] KSH, Statisztikai Tükör, 2015. április 1. http://www.ksh.hu/ docs/hun/xftp/stattukor/halapenz.pdf. [Hungarian]

[11] Horváth, F., Terebessy, A., Balázs, P.: Fourth-year medican students' views about informal payment in Hungary. [A hálapénzkérdés értékelése IV. éves orvostanhallgatók körében.] Lege Artis Med., 2011, 21(8-9), 559-563. [Hungarian]

[12] Physicians about the informal payment. [Orvosaink a hálapénzról.] Szinapszis Kft. kutatási jelentés, 2009. http://www.szinapszis.hu/kutatasi_eredmenyek/12/print [Hungarian]

[13] Informal payment. Who, how much waiting for? [Hálapénz. Ki mennyit vár?] Szinapszis Kft. Kutatási jelentés, 2013. lwebcache. googleusercontent.com/search?q=cache:Jl3qFoey7sQJ:rezide
ns.hu/index.php/sajtoanyag/letoltesek\%3Fdownload\%3D17:imrsz-szinapszis-halapenz-bemutato $+\& \mathrm{~cd}=12 \& \mathrm{hl}=\mathrm{hu} \& \mathrm{ct}=\mathrm{clnk}$ $\& \mathrm{gl}=\mathrm{hu}$. [Hungarian]

[14] Association of American Medical Colleges: AAMC data book: medical schools and teaching hospitals by the numbers. American Association of Medical Colleges, Washington, 2009

[15] OECD: Physicians by age and gender, 2012. (OECD Health data: health care resources. OECD Health Statistics.) http:// stats.oecd.org/

[16] Levinson, W., Lurie, N.: When most doctors are women: what lies ahead? Ann. Intern. Med., 2004, 141(6), 471-474.

[17] Györffy, Zs.: Female physicians in Hungary. [Orvosnők Magyarországon.] Semmelweis Kiadó, Budapest, 2015. [Hungarian]

[18] BMA: Statistics of medical students in the U.K. British Medical Association, Health Policy and Economic Research Unit, London, 2002.

[19] Reichenbach, L., Brown, H.: Gender and academic medicine: impacts on the health workforce. BMJ, 2004, 329(7469), 792795.

[20] Riska, E.: Towards gender balance: but will women physicians have an impact on medicine? Soc. Sci. Med., 2001, 52(2), 179187.

[21] Central Statistical Office: Statistical Yearbook of Hungary 2011. [Központi Statisztikai Hivatal: Magyar Statisztikai Évkönyv 2011]. KSH, Budapest, 2012. http://www.ksh.hu/docs/hun/ xftp/idoszaki/evkonyv/egeszsegugyi_evkonyv_2012.pdf [Hungarian]

[22] Varga, J.: Where have all the doctors gone? Migration and attrition of physicians and dentists in Hungary between 2003 and 2011. [Hová lettek az orvosok? Az orvosok külföldre vándorlása és pályaelhagyása Magyarországon 2003-2011.] Budapesti Munkagazdaságtani Füzetek. BWP - 2015/6. MTA Közgazdaság- és Regionális Tudományi Kutatóközpont, Közgazdaságtudományi Intézet, 2015. http://www.econ.core.hu/file/ download/bwp/bwpl506.pdf [Hungarian]

[23] Györffy, Zs., Csala, I., Sándor, I.: Medical students of Hungary. A changing profession or feminisation? [Orvostanhallgatók Magyarországon: átalakuló vagy elnőiesedő hivatás?] Orv. Hetil., 2013, 154(49), 1950-1958. [Hungarian]

(Torzsa Péter dr., Budapest, Kútvölgyi út 4., 1125 e-mail: ptorzsa@gmail.com)

\section{ELADÓ}

Orvosi rendelőnek, irodának is alkalmas színvonalasan felújitott 94 m²-es lakás, Budapest XIII. kerületében, a Váci úton (Lehel piac közelében) eladó.

Felszereltség: klíma, 3 fázis, telefon és info-hálózat, beépitett konyhabútor, 2 db WC.

Irányár: 40 millió $\mathrm{Ft}$.

Telefon: 06-20-448-4211 